\title{
THE SHORT AND LONG-TERM RELATION BETWEEN HUMAN DEVELOPMENT AND FEMALE UNEMPLOYMENT: THE CASE OF TURKEY
}

This study aimed to measure the short and long-term relation between female unemployment and the basic factors for society's human development, namely education, health conditions and income levels, therefore it was important to test the effect of inflation in the equation which deals with unemployment. The study covered the years from 1990 to 2016, and used the United Nations Development Programme's (UNDP) Human Development Index (HDI) to measure human development and the obtained real human development values for Turkey. To analyse the effects of real human development, information and communication technologies (ICT) and inflation on female unemployment, the Autoregressive Distributed Lag (ARDL) bounds test and the Engle-Granger test was used. As a result of the analysis, a reasonably strong, significant and negative relation was found between human development and female unemployment in the long term.

Keywords: human development, female unemployment, ARDL bounds test, Turkey

JEL Classification: J24, E24, O11, O15

DOI: $10.15611 /$ aoe.2021.2.10

\section{INTRODUCTION}

Increases in the production capacities of countries constitute the most important factor for economic growth and development around the world. High levels of labour force participation rate in a country's population imply that the country's resources are effectively used. In this way, the country's production capacity and national income rise and the overall welfare level increases. Does an increase in the basic dynamics of development lead to an improvement in the female labour force as in the overall welfare level?

Although women contribute to every phase of production throughout human history, they are not given their due share in the opportunities of development, and they constitute the social group that is most affected by

\footnotetext{
* Faculty of Economics and Administrative Sciences, Bingol University, Bingol, Turkey.

** Independent Scholar.
} 
poverty. Studies on female participation in the labour force generally focus on how to enhance women's employment or examine the effects of gender equality on macroeconomic data. It is known that there are numerous factors related to the realization of macroeconomic indicators other than women's employment. Yet it is also true that any increase in female employment will have more social effects than economic ones. Accordingly, this study investigates the existence of a relationship not from female unemployment to macro data, but from macro data to female unemployment. Human development index (HDI) variables were used as macro data and the effect of basic variables related to human development (education, health and income) on female unemployment was studied.

As is known, human development has emerged as a concept considered more important than growth in our globalizing world. Human development does not refer to growth solely in economic terms, but also takes into consideration the improvement in the social and cultural aspects of society. As such, it is a more comprehensive concept. The human development index is calculated assuming the existence of three basic factors that influence economic, social and cultural improvement. These basic factors comprise schooling and literacy rates for education, life expectancy at birth for health and per capita national income for income. The aim of this study was to measure how the changes in these variables used to measure human development affect female unemployment. It is important to include the inflation rate in the variables during this measurement so that the topic can be better understood, hence the omitted variable bias can be minimized. In this way, the factors that affect female unemployment can be demonstrated more effectively. Moreover, the rapidly developing information and communication technologies (ICT) in the globalized world were examined as a control variable on women's unemployment.

This study first provides general information on female unemployment and the nature of the female labour force in Turkey and then moves on to explain the basic dynamics of human development, followed by a review of the national and international literature on the subject and focuses on the explanation of methodology and empirical findings. Information on how the variables used in the methodology were obtained, the process of development of the time series in the period 1990-2016 in Turkey, and the methods used in econometric analysis were also provided. In the empirical findings, the level of the relation between the basic components of development and female unemployment in Turkey was identified. In the conclusion, the results were evaluated within the framework of the government policies. 


\section{FEMALE UNEMPLOYMENT IN TURKEY}

Unemployment, especially female unemployment, is a complex phenomenon that is open to influence from many variables, including those individual, social and economic. Despite the fact that about half of the world's population is female, the employment rate of women is not proportional to the population. To boost labour productivity and, with it, growth, the participation of women in the labour force should be enhanced. An increase in women's employment would up push average household income (Mitra et al. 2015), which in turn would augment the welfare level. As shown by Duflo (2012), if a larger part of the household income is spent on investing in health and education, the exclusion of young women would decline, making it possible for them to find jobs more easily and reducing female unemployment in the long run. For a fairer employment structure to be developed, both government and individuals should be able to formulate macro policies with social consensus.

In this context, comparisons can be made between the OECD countries and Turkey regarding the female labour force. In 2016, the OECD country average for female unemployment was $7 \%$, while this rate was $13.7 \%$ in Turkey, ranking 32nd among the OECD countries. The rate of female employment was $30.1 \%$, far below the OECD average of 58.2\% (OECD Data, 2016), while the rate of participation of women in the labour force was 33.6\% in Turkey, compared to the OECD average of $62.8 \%$ (OECD Stat, 2016).

On the other hand, a relative increase has been observed over the years regarding the rate of female participation in the labour force in Turkey, which increased from $33.6 \%$ in 2014 to $38.7 \%$ in 2019 (TUIK Data, 2020).

Despite the fact that these statistics place Turkey in the lower ranks among the OECD countries in terms of the female labour force level, the positive developments in the areas of human development in Turkey can be seen as a policy of increasing female labour force participation rate since the participation rate of women in education at all levels is increasing every year in Turkey, and incentive policies are implemented in this direction. For instance, according to data from TUIK (the Turkish Statistical Institute), the rate of women's participation in higher education in Turkey increased each year between 20072019. In this context, while this rate increased by $33.6 \%$ in 2007 compared to the previous year, it grew to $107.4 \%$ in 2018 (TUIK Data, 2020). The participation rate in education raises the level of development as it is a component that affects the increase of HDI. Therefore, it is thought that women becoming more educated and aware will also increase their employment. 
The labour force participation rate has always been higher for men than women in Turkey, as a result of the patriarchal family structure, the educational status of women and their families, and the factor of female marriage at an early age etc. The labour force participation rate for women is higher in rural areas than urban areas. In the former, women are generally employed as unpaid family workers, and they fail to compete with men in terms of participation in the labour force because they lack, or are deprived of, sufficient education and work experience in cities (Palaz, 2005). In this context, it is of crucial importance to promote academic and political efforts to boost female employment in Turkey.

Turkey is developing strategies to increase the participation rate of women in the workforce. For example, the National Employment Strategy, which came into force in 2014, adopted a target for women as a labour force participation rate of $41 \%$ by 2021 .To achieve this objective a strategy of "Encouraging arrangements to prevent women who have children to leave the labor market" has been accepted as a method (Ministry of Labor and Social Security, 2014). Although statistically, female labour force participation is low, the government offers important and valuable incentives in this regard. Women are encouraged to be more active not only in the labour market, but also in politics and non-governmental organizations. Moreover, one can say that the awareness and desire of women to participate in the workforce is increased with each passing year.

\section{THE BASIC DYNAMICS OF HUMAN DEVELOPMENT}

Development problems are one of the basic work areas of development economics, and has a quite different content from the economic growth concept and these should not be confused. One of the key elements in measuring economic development is the economic growth, considered in many studies. In fact, development in different countries is matter of the process of change process achieved with several methods. Since measures on information with regard to the progress of such development is needed, components such as human development, integration of information at home, industrial framework, quality of life and the environment cannot be found in GDP (Navarro et al. 2014).

However, development expresses a concept larger than growth. Taban and Kar (2014) defined the development as the improvement of the economic structure of an underdeveloped society, changing and renewing its cultural and political structures. In other words, as well as an increase of per capita income, structural changes such as changes in efficiency and number of manufacturing factors, the percentage increase of the industry sector in 
national income and exports constitute the basic factors of development (Taban and Kar, 2014).

To gain a new perspective on development by putting the human factor into focus, the human development concept has emerged and various studies have been conducted on this subject. It can be said that the foundations of human development were laid according to Amartya Sen's 'able to docapability' approach, i.e. having the potential and ability to do something or to gain functionality. In this scope, the increase of a person's realizations during their life expresses a people-oriented development. Sen (1997) stated that it should not be disregarded that for an individual to do (or to be) something, one should have characteristics such as personal characteristics, social background and economic conditions - values which may occur directly (related to enriching one's life such as being well fed or healthy) or indirectly (contributing more to manufacturing or doing price controls in the market), increasing human abilities, welfare and freedom is closely related with economic production and social change (Sen, 1997).Nussbaum described the abovementioned views with the concept of the threshold level of capabilities, which can provide the basis for the central constitutional principles that citizens have the right to request from their administration (Nussbaum 2000).

As seen from this point, for the realization of a people-oriented development, merely improving the income level is not sufficient, it is also required to increase freedoms which will contribute to economic, social and cultural development. Sen (1999) interpreted human development as a process for the extension of freedoms, stated that National Income increases the freedoms of people. However, this is not sufficient as it is also linked to other factors such as civil and political rights (for example, freedom of participating in monitoring democracy) as well as economic and social arrangements (such as education and health services) (Sen, 1999). In addition, access to ICT is also an important part of development. Greater access to ICT, starting with basic communications infrastructure, could significantly improve the living standards of the world's rural poor by enhancing the functioning of relevant markets (Eggleston et al. 2002).

Increasing human development has a close correlation with popularizing the concept of the welfare state understanding, which has a regulatory and supervisory impact on the market economy. Within this scope, Briggs (1999) described the welfare state as a utilization of public power in the market in an organized manner, aimed at reducing the efficiency of market forces. According to Briggs, it is necessary to emphasize three fundamental areas in using this power. The first one is ensuring a minimum income for individuals and their families independently of the economic conditions in the market. The second one is limiting the scope of precarity against social risks which may lead them 
to fall into a crisis (sickness, senility, unemployment etc.) unless precautions are taken. The third, is ensuring that good standards of social services are reached by society without making any class or statute discrimination (Briggs, 1999).

Furthermore, it can be said that a more suitable background is prepared for the improvement of human development in social welfare states in which economic and social transformations are enhanced between the State and the society. This is due to the significant proximity observed between the objectives and targets of a welfare state, and aspects covered by human development.

\section{LITERATURE REVIEW}

In this study, the female labour force was taken as the dependent variable, while the basic factors of human development were treated as independent variables. In other words, the female labour force variable was considered as the effect, not as the cause. A perusal of the analysis in the literature reveals that some studies took human development factors as the independent variable and the female labour force as the dependent variable in examining the relation between these two variables while there were studies that took the opposite approach.

In the studies that focused on the factor affecting women's unemployment, i.e. which took female unemployment as the dependent variable, diverse factors were found to influence female unemployment, such as education, income levels, health, socio-cultural and demographic factors, and other factors. Hill and King (1995) found that while education led to labour market productivity and revenue growth for everyone, an increase in the rate of schooling of girls at every level of education would enhance family health, increase productivity and the employment of women and in particular push up the economic welfare level. Arguing in this context that the level of education affects the female labour force, Uraz et al. (2010) concluded that there is a strong causal link between education level of women and their labour force participation rate in cities in Turkey, but education did not have much effect on it in rural areas. Likewise, Tatli (2015) and Kavak (1997) showed that as the level of women's education became higher, the female labour force participation rate increased, minimizing the gap between the genders in Turkey. Tansel (2002) found that Turkey's high growth rate and education level enhanced women's labour force participation rate.

Pointing out that there is a dual close relation between economic development and women's empowerment and increased female employment, Duflo (2012) argued that women's empowerment leads to improvement in some aspects of children's welfare (health and nutrition, in particular), but at the expense of some others (education). 
Several studies on the female labour force identified that the factors affecting it are related to income (growth and wage levels, etc.) In this context, Baslevent and Onaran (2004) used official household labour force survey data and found that long-term export-oriented growth in Turkey made a positive impact on the participation of women in the labour force and female employment. Kasnakoglu and Dayığlu (2002) argued that the main reason for the low rate of labour force participation for women was that the level of the lowest wage acceptable to women (which is equal to the total sum of women's production at home) is higher than the wage level available in the market. The study by Uraz et al. (2010) lends support to this argument. Thus, hourly wages of low-skilled men are 1.4-1.5 times higher than average hourly wages of women in urban areas. The huge difference between the hourly wages of low-skilled men and women has a negative impact on women's labour force participation rates.

In some studies that took female employment variables as the independent variable, it was argued that female employment variables influence such factors as economic growth and development. Klasen (1999), for example, examined the extent to which gender inequality reduces growth and development. He found that gender inequality in education lowers the average quality of human capital and has a direct effect on economic growth. There are other studies indicating that the labour force participation of women and gender equality are major factors of economic growth, such as Lahoti and Swaminathan (2016), Mitra et al. (2015), Elson (2009) and Seguino (2000). Berik et al. (2009) argue that gender inequality in education and wages has macroeconomic effects and this has an adverse effect on growth and development. Likewise, in their study on a number of countries including Turkey, Klasen and Lamanna (2009) concluded that gender inequalities in education and employment generally have adverse effects on economic growth. Wagman and Nancy (1996) indicated that the non-market household services provided by women played a role in the growth and development of the US economy between 1870 and 1930. Wanjala and Maureen (2009) argued that despite the fact that they produce more benefits, women are employed with lower wages, which in turn is guided by gender inequality. They suggested that the government should implement policies to the support active participation of women in the labour market as gender equality has a positive impact on employment and growth.

Innovations in information and communication technologies have a positive impact on company performance at micro level and increase production. This positive contribution can affect the economic growth 
positively at macro level. Innovations consist in the result of the positive progress in ICT and increase the amount of production; in the increased production process, employment opportunities emerge and unemployment decreases. In recent years, studies have been conducted on the relation between ICT and unemployment. The findings of these studies suggest that ICT provide a positive contributions to the economy and reduce unemployment. For instance, Ugur and Turan (2016) analysed with the G-20 panel data the effect of ICT on employment level. In the period 1991-1999, the effect of ICT on employment was positive and significant for developed countries, but positive and insignificant in developing countries. In the period 2000-2012, the effect of ICT on employment was significant and negative in the developed countries, but in the developing countries, significant and positive. In another study by Alper (2017), one can see that similar outcomes were obtained. In this study, the impact of ICT on economic growth and unemployment was examined for 24 countries. In addition, the feasible generalized least squares method was applied by using the annual data for 1996-2016 (Alper 2017). Tt was found that ICT contributed positively to economic growth and decreased unemployment. In other studies, it was also concluded that ICT usage increased economic growth (Turedi 2013; Artan et al. 2014; Pradhan et al. 2018, etc.).

\section{METHODOLOGY}

In this section, information is provided on the model and variables used and their sources, and the time series methods employed are briefly described.

\subsection{Data set and variables of the study}

Information about the data related to the variables used in the analysis is given in Table 1.

Table 1

Analysis variables and definitions

\begin{tabular}{l|l|l}
\hline \multicolumn{1}{c|}{ Variable } & \multicolumn{1}{|c}{ Description } & \multicolumn{1}{c}{ Reference } \\
\hline FUR & Female unemployment rate (\%) & The World Bank Database* \\
\hline Real_HDI & $\begin{array}{l}\text { Real Human Development Index in } \\
\text { Turkey }\end{array}$ & $\begin{array}{l}\text { The Turkish Statistical Institute and } \\
\text { HDI formula. }\end{array}$ \\
\hline$I C T$ & Mobile cellular subscriptions & The World Bank Database* \\
\hline$P P I$ & $\begin{array}{l}\text { The average annual percentage change } \\
\text { in the producer price index }(\%)\end{array}$ & The World Bank Database \\
\hline
\end{tabular}

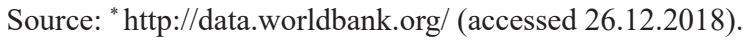




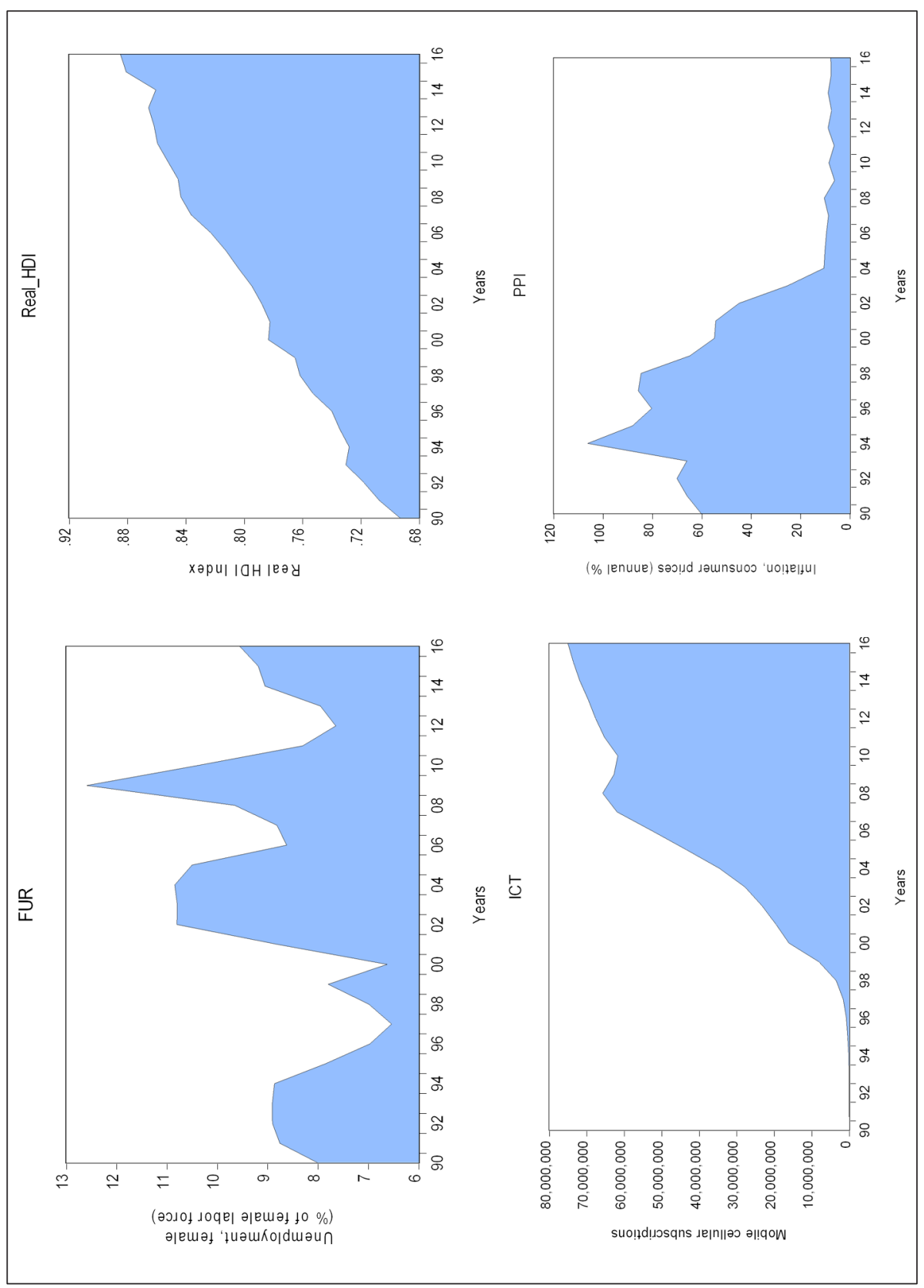

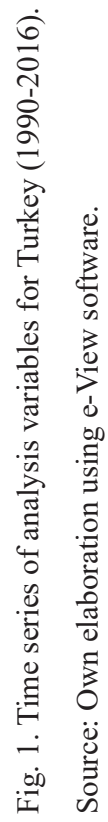


Nowadays, as a result of the rapid improvements in ICT, mobile internet and smartphones have become part of everyday human life, which has made access to information cheaper and easier for everyone, especially women. This has weakened the strict rules in patriarchal societies and contributed to women's self-discovery and self-realization. Furthermore, innovations in this field provide new job opportunities for women. In this context, ICT were added to the econometric model.

The charts related to the time series of the variables used in the study are shown in Figure 1, where the course of the cyclical fluctuation over time can be seen.

\subsection{Study model and econometric techniques}

Female unemployment is a subject of economics that deserves a multifaceted approach. Accordingly, this study adopted a multidimensional perspective in dealing with female unemployment. In this context, the method for calculating the human development index (HDI), calculated by the United Nations Development Programme (UNDP), was adopted and the data related to Turkey were collected. The UNDP method was used on these data to calculate the real HDI. Equation (1) used to obtain the analysis results as follows:

$$
\ln F U R_{t}=\beta_{0}+\beta_{1} \ln R e a l_{-} H D I_{t}+\beta_{2} \ln I C T_{t}+\beta_{3} \ln P P I_{t}+\varepsilon_{t} .
$$

In Equation (1), $\ln F U R$ is the natural logarithm of female unemployment rate, lnReal_HDI is the natural logarithm of the Real Human Development index, $\ln I C T$ is the natural logarithm of information and communication technology, $\ln P P I$ is the natural logarithm of annual average percentage change of the producer prices index, and $\varepsilon_{t}$ is the error term.

$\ln F U R$ was the dependent variable while $\ln$ Real_HDI, $\ln I C T$, and $\ln P P I$ were the independent variables. Annual data from the 1990-2016 period were used in the analyses for Turkey. The variables used in the study were identified in light of the economic theory and empirical studies.

First, the stationarity of the series was tested using the Augmented DickeyFuller (ADF) $(1979,1981)$ and the structural break test of Zivot, and Andrews (1992) methods. Then, the presence of co-integration between the series and long and short-term analysis was determined using the ARDL bounds test. In addition, the causality relationship between FUR and Real_HDI, ICT and PPI variables was investigated.

Accordingly, the econometric model was based on the cointegration test, developed by Pesaran et al. (2001). The used methods are based on residuals 
and commonly used to determine the cointegration relationship between the series and were developed by Engle and Granger (1987), Johansen (1988), Johansen and Juselius (1990). The Engle and Granger method was not preferred as there may be multiple cointegration relationships in cases of more than two variables. For the Johansen (1988) and Johansen and Juselius (1990) tests, all series should not be stationary at the level, and should be stationary when their difference is obtained on the same degree. These disadvantages have led to the development of the Autoregressive Distributed Lag (ARDL) bounds test. In this method both long-term and short-term relationship between the variables can be tested regardless of $\mathrm{I}(0)$ or I(1). The various advantages of the ARDL analysis method were discussed in literature, namely that it produces robust and effective results even with small samples (Narayan and Narayan 2004), and it integrates with short-term dynamics without losing the long-term balance and long-term information thanks to the error correction model (ECM) (Narayan and Narayan 2004).

\subsection{The Real Human Development Index in Turkey}

When the Human Development Report (HDR) was published in 1990, the UNDP publicized the index measuring human development and included it in the development economy literature as HDI for the first time through an official institution.

It is accepted that humanity should progress with economic, social and cultural aspects and significantly contribute to increase the social welfare levels of people. Within this framework, human development can become measurable depending on concrete data such as HDI. This facilitated the issue to be understood better and created a significant resource for scientific studies, thus the importance of human development has increased. By means of this index, countries have access to relevant opinions as to which direction they should progress in their social welfare levels. It is also visible that this matter has become an important discussion topic among recent economic events.

The concept of human development is not explained solely by economic performance, but rather by increasing the welfare levels of people and the sustainability of it. Within this scope, the benefits created by economic growth can be transformed to the quality of life(Jahan, 2002). Three main parameters are used in the generation of HDI, which is one of the developed indexes to measure this. The first one is health and having a long life, which is measured by average life expectancy; the second one is education and information level measured by literacy and schooling rate; and the third one is life standard measured by using GDP per capita, which is calculated according to purchasing 
power parity (in other words, with foreign exchange rates which reflect transnational relative price differences) (UNDP, 2011).

The value of $H D I$ varies between 0 and 1 . As the index value approaches 1 , it shows that human development performance improves and if it approaches 0 , it gets worse. In its report, the UNDP grouped countries into three categories as having low, medium and high human development according to its calculations (Keskin, 2011; Taban and Kar 2006). After adding countries with very high human development in recent years, now there are four categories.

In this report, by making a formulation amendment in $H D I$ calculations from time to time, human development has been reflected more accurately. However, due to formulation amendments, comparability of country data by year has degenerated. To remove this deficiency, the UNDP re-calculates and publishes at 5-year intervals, calculating the data belonging to the previous period by using the last determined formula. This situation has led to changes in the previous years' grading of countries, and in HDI scores (Demir 2006). In any case, since new calculations are made in 5-year intervals, changing the new index values of intermediate years cannot be carried out.

It is possible for countries to have changes in previous years' values or country grading because of these amendments. When taking into account the calculation amendments made in the index for 1990, 1991, 1994, 1995, 1999 and 2010, it is apparent that six different calculation methods have been utilized so far.

In this study, $H D I$ values of the UNDP were not directly used and index values for the period 1990-2016 were re-calculated based on real values. The rationale for this calculation to be redone and differences between two calculations are listed below:

- when calculating the index values of the UNDP, six different calculation methods were applied. For this reason, the data value of each year is not equivalent and measurable. However, the index values used in this study were calculated using the formula most used by the UNDP according to the year (between 1999 and 2010).

- when calculating the index values, the UNDP used data from various institutions such as the United Nations Population Department (UNPD), the UNESCO Statistics Institute and the World Bank. In this study, values indicated in HDRs were not considered and the entire data re-calculated based on data from the Turkish Statistical Institute in order to reach the real index values.

- The data taken into consideration from the index calculations of each year before 2010 in the UNDP reports were from 2 years ago. For this reason, it was not possible to conduct the exact desired analyses by means of the 
UNDP data. The index values calculated for each year in this study were calculated as current and real by using the data of the corresponding year. The common directions of the two calculations were as follows:

- The fundamental components used by the UNDP in the index calculation, and the fundamental components used in this study have the same qualification. These are 'health' for a long and healthy life, 'education' to access the information and 'income' for a decent quality of life.

- The sub-variables of these fundamental components are the same as the ones used between 1990 and 2010. Of these, what is taken into consideration for the sub-variable of the health fundamental component is "average life expectancy at birth", and for education "literacy rate in adults" and "gross schooling rate", and for income "GDP per capita".

- The formulas used by the UNDP for the index calculation between 1999 and 2010, and the formulas used in this study are the same. The used formulas are as below:

$$
\begin{gathered}
H D I=(\text { life expectancy in sub-index }+ \text { education sub-index }+ \\
\text { GDP per capita in sub-indices }) /
\end{gathered}
$$

Health sub-index $=$ (real value - minimum value) / (maximum value - minimum value)

Education sub-index $=$ (real value -minimum value $)$ / (maximum value - minimum value)

GDP per capita in sub-indices $=[\log (y)-\log (y \min )] /$

$$
\text { [log }(y \max )-\log (y \min )]
$$

The real index values for 1990-2016 for Turkey were calculated using these formulas and the index values were based on different formulas in the UNDP's report. Both are shown in the figure below clearly and comparatively.

Look at Figure 2, it is visible that there are rapid and sudden fractures in the index values of the UNDP, especially in certain years. The basic reason of this is the formulation amendment made in the index calculations in these years. When looking at the real $H D I$ values calculated without the formulation amendment, rapid fractures are not observed and there are only relative fluctuations occurring in some periods.

In the past decade in Turkey, a recovery in human development was achieved, And some of the reasons for this progress are as follows: pregnancy and neonatal screening for women, family medical care available to every citizen, increased t number of hospitals and health clinics, increased the duration of compulsory education to 12 years, growing number of higher education graduates with the establishment of a university in each province, 


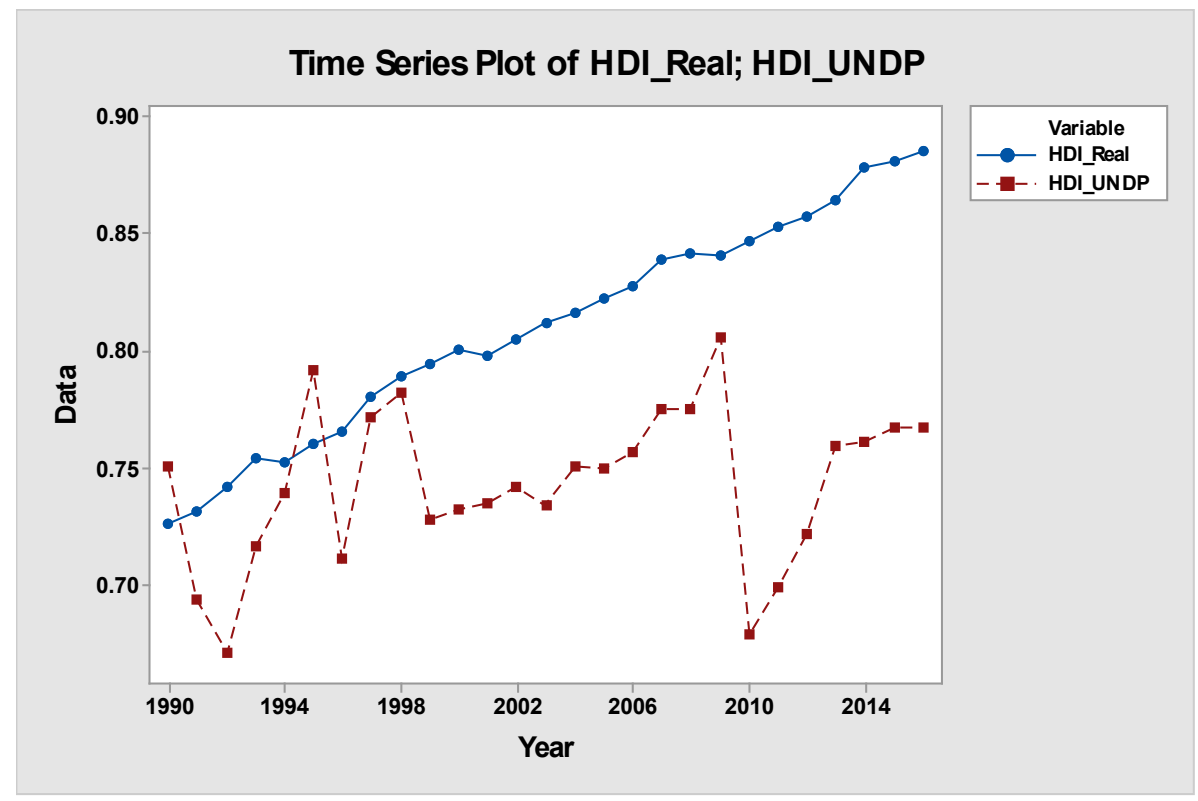

Fig. 2. HDI_Real and HDI_UNDP Values (1990-2016).

Source: HDI_UNDP data has been compiled from HDRs and HDI_Real has been generated by authors according to HDI formula (1999-2010) by taking into consideration the Turkish Statistical Institute data.

and increased income per capita, etc. Investigating these reforms which contributed to the reduction of female unemployment in Turkey and examining the components of human development is crucial.

\section{FINDINGS}

In this section the stationarity test results of the variables to be used in the analysis were given, and then cointegration test results and the ARDL bounds test results were provided.

\subsection{ADF unit root test findings}

In the ARDL bounds test, none of the variables in the model should be I(2). This is because the lower and upper critical values provided by Pesaran et al. (2001) were derived based on whether the series were I(0) and I(1). To this end, the stationarity of the variables was examined according to the Augmented Dickey-Fuller (ADF)and Phillips-Perron(PP) Unit Root Tests before the 
application. The null hypothesis of the $\operatorname{ADF}\left(\mathrm{H}_{0}\right)$ implies that there is a unit root, i.e. the series are not stationary while the alternative hypothesis $\left(\mathrm{H}_{1}\right)$ suggests that there is no unit root, i.e. the series are stationary. If, as a result of the unit root tests, $\mathrm{H}_{0}$ is rejected, the series is considered as stationary and if $\mathrm{H}_{0}$ cannot be rejected, it is not stationary. The results of the stationarity tests related to the variables are summarized in Table 2.

Table 2

Unit root test results

\begin{tabular}{l|c|c|c|c}
\hline \multirow{2}{*}{ Variables } & \multicolumn{2}{|c|}{ ADF } & \multicolumn{2}{c}{ PP } \\
\cline { 2 - 5 } & Intercept & Intercept and Trend & Intercept & Intercept and Trend \\
\hline \multirow{2}{*}{ FUR } & -2.264 & -3.129 & -2.264 & -2.236 \\
\cline { 2 - 5 } & $(0.191)$ & $(0.122)$ & $(0.190)$ & $(0.402)$ \\
\hline \multirow{2}{*}{ Real_HDI } & -0.981 & -2.929 & -1.476 & -2.978 \\
\hline \multirow{2}{*}{ PPI } & $(0.744)$ & $(0.170)$ & $(0.559)$ & $(0.157)$ \\
\hline \multirow{2}{*}{ ICT } & -0.684 & -2.073 & -0.660 & -2.536 \\
\cline { 2 - 5 } & $(0.834)$ & $(0.536)$ & $(0.840)$ & $(0.239)$ \\
\hline \multirow{2}{*}{$\Delta$ FUR } & -2.578 & -2.835 & -1.357 & -2.880 \\
\cline { 2 - 5 } & $(0.110)$ & $(0.203)$ & $(0.586)$ & $(0.184)$ \\
\cline { 2 - 5 }$\Delta$ Real_HDI & $-4.190^{* * *}$ & $-4.093^{* *}$ & $-4.178^{* * *}$ & $-4.043^{* *}$ \\
\cline { 2 - 5 } & $(0.000)$ & $(0.018)$ & $(0.003)$ & $(0.020)$ \\
\hline \multirow{2}{*}{$\Delta$ PPI } & $-6.556^{* * *}$ & $-6.549^{* * *}$ & $-6.709^{* * *}$ & $-6.968^{* * *}$ \\
& $(0.000)$ & $(0.000)$ & $(0.000)$ & $(0.000)$ \\
\cline { 2 - 5 } & $-5.208^{* * *}$ & $-5.089^{* * *}$ & $-2.208^{* * *}$ & $-5.089^{* * *}$ \\
\hline \multirow{2}{*}{$\Delta$ ICT } & $(0.000)$ & $(0.000)$ & $(0.000)$ & $(0.002)$ \\
\cline { 2 - 5 } & $-2.769^{*}$ & $-4.666^{* *}$ & $-2.883^{*}$ & $-4.622^{* * *}$ \\
\hline & $(0.077)$ & $(0.010)$ & $(0.061)$ & $(0.006)$ \\
\hline
\end{tabular}

Note: $* * * p<0.01, * * p<0.05, * \mathrm{p}<0.10 . \Delta$, indicates the first difference of the variables.

Source: authors calculations in EViews.

According to the results of the ADF and PP unit root test, it was concluded that the all the variables are not stationary at the level I(0), but they became stationary when the first difference I(1) was taken. Therefore, these variables are stationary at the first difference. There is a requirement that the dependent variable in the ARDL model should be I(1) and also none of the variables planned to be used in the analysis should be I (2). Given these results, 
cointegration between variables were tested using the ARDL bounds test approach.

There may be changes in the economic variables due to the economic conditions and different processes that occurred during the time period analysed in the analyses made depending on the time series. Such changes may cause structural changes in the series. Therefore, it was necessary to test whether the series of variables were affected by structural breaks. Perron (1989) reported that, when the series had structural breaks, the strength of the traditional ADF Test weakened and caused that the deviation towards the unitroot-base hypothesis was not rejected. Thus, it was tested whether the series of variables in the study were affected by structural breaks. This test was performed with the Zivot and Andrews (1992) structural break unit-root test which tested the stability under structural break. This test determined endogenously the structural breakpoints occurring in the series.

Table 3

Zivot-Andrews Unit Root Test

\begin{tabular}{l|l|l|l|l}
\hline & \multicolumn{2}{|c|}{$\begin{array}{c}\text { With intercept } \\
\text { only }\end{array}$} & \multicolumn{2}{c}{ With intercept and trend } \\
\hline Variable & Min. t-statistic & Break Period & Min. t-statistic & Break Period \\
\hline FUR & $-3.606(1)$ & 1996 & $-4.419(1)$ & 2001 \\
\hline Real_HDI & $-3.936(0)$ & 1997 & $-4.007(0)$ & 2001 \\
\hline ICT & $-3.858(3)$ & 2004 & $-2.690(3)$ & 2010 \\
\hline PPI & $-3.972(0)$ & 2003 & $-3.707(0)$ & 2003 \\
\hline Critical Values: & & $\begin{array}{l}\text { Critical Values: } \\
1 \%-5.57\end{array}$ \\
$1 \%-5.34$ & & $5 \%-5.08$ & \\
$5 \%-4.93$ & & &
\end{tabular}

Note: the values in parentheses indicate the number of lags. Critical values of both models are taken as Zivot and Andrews (1992: 258).

Source: authors calculations in EViews.

Table 3 demonstrates that, in the constant of the series, the test statistics constituted for constant and trend break are in the structural break periods determined according to $t$ statistics. All the variables, for both the intercept, and intercept and trend models, cannot reject the null hypothesis of structural break unit root. Therefore, the results of the Zivot-Andrews unit root test show that the structural breaks in the series did not significantly affect the traditional ADF Unit Root Test results and all the series were I(1). 


\subsection{Cointegration and the ARDL-bounds test}

In the ARDL-bounds test, the primary aim is to identify if there is a longterm relation between the variables of the model. Thus, first an Unrestricted Error Correction Model (UECM) was created. As the cointegration analysis is sensitive to the number of lags, a systematic process should be adopted in picking up the number of lags. The number of maximum lags for the study was set to be 2 as the data were annual.

Another important point that should be taken into consideration was to determine whether there is a time trend in the cointegration equations (Pesaran et al. 2001). Hence during the cointegration test phase, UECM estimates with and without the deterministic trend were made in addition to the standard information criteria (AIC and SBC). The deterministic trend was found to be not significant in the model created, thus it was not included in the analysis. The adaptation of this test, based on the UECM, is given below:

$$
\begin{aligned}
\Delta \ln F U R_{t}= & \beta_{0}+\sum_{i=1}^{m} \beta_{1, i} \Delta \ln F U R_{t-i} \sum_{i=0}^{m} \beta_{2, i} \Delta \ln \text { Real }_{-} H D I_{t-i}+\sum_{i=0}^{m} \beta_{3, i} \Delta \ln I C T_{t-i}+\ldots \\
& \sum_{i=0}^{m} \beta_{4, i} \Delta \ln P P I_{t-i}+\beta_{5} \ln F U R_{t-1}+\beta_{6} \ln R e a l_{-} H D I_{t-1}+\ldots \\
& \beta_{7} \ln I C T_{t-1}+\beta_{8} \ln P P I_{t-1}+\hat{n}_{t}
\end{aligned}
$$

The null hypothesis and the alternative hypotheses of the untrended model, created to test the cointegration relationship among the variables in Equation (6), were respectively $H_{0}: \beta_{5}=\beta_{6}=\beta_{7}=\beta_{8}=0, H_{1}: \beta_{5} \neq \beta_{6} \neq \beta_{7} \neq \beta_{8} \neq 0$. The relation between the variables was determined by collectively testing the significance of coefficients $\beta_{5}, \beta_{6}, \beta_{7}$, and $\beta_{8}$ (in Equation 6) using $F$ test (the Wald test). To identify the cointegration relationship between the variables, the calculated statistics should be compared to the critical limit values in Pesaran et al. (2001). As annual data were used in this study, the model was estimated with a maximum two lags and without trend. The results of $F$ statistics related to the testing of the cointegration relationship are given in Table 4.

$F$ statistics was 8.013 , implying that the variables were cointegrated. This exceeds the upper bound even at the $1 \%$ significance level of critical values (Table 4), therefore the null hypothesis that suggests no long-term cointegration relationship among FUR, Real_HDI, ICT and PPI was rejected. Accordingly, one can say that there was a long term-term relation among the variables in question for the period from 1990 to 2016 for Turkey. 
Table 4

Cointegration test results

\begin{tabular}{c|c|c|c|c}
\hline Model & $\mathrm{m}$ & $\mathrm{k}$ & F-statistic & $\mathrm{I}(0)$ and $\mathrm{I}(1)$ Critical Values \\
\hline & & & & $4.614-5.966^{* * *}$ \\
\hline ARDL $(2,1,1,0)$ & 2 & 3 & 8.013 & $3.272-4.306^{* *}$ \\
\hline & & & & $2.676-3.586^{*}$ \\
\hline
\end{tabular}

Note: ${ }^{* * *},{ }^{* *}$ and ${ }^{*}$ express respectively $1 \%, 5 \%$ and $10 \%$, significance levels. $\mathrm{m}$ is the number of maximum lags and $\mathrm{k}$ the number of independent variables in the model. Critical values were obtained from Narayan (2005:1988), case (III).

Source: authors calculations in EViews.

In the next stage that comes after identifying the long-term relations among the variables, the ARDL model had be estimated to analyse the short and longterm relations among the variables. The ARDL model, as adapted to this study to analyse the relations is given below:

$$
\begin{aligned}
\ln F U R_{t}= & \beta_{0}+\sum_{i=1}^{p} \beta_{1, i} \ln F U R_{t-i}+\sum_{i=0}^{q} \beta_{2, i} \ln \text { Real }_{-} H D I_{t-i}+\sum_{i=0}^{v} \beta_{3, i} \ln I C T_{t-i}+\ldots \\
& \sum_{i=0}^{z} \beta_{4, i} \ln P P I_{t-i}+\varphi_{t}
\end{aligned}
$$

To determine the most appropriate ARDL model using the e-View program, Equation 7 was estimated using the OLS approach for all the possible values of $p, q, v$ and $\mathrm{z}=1,2, \ldots, m$ and $i=1,2, \ldots, k$. In this estimation, the maximum lag length $(m)$ was taken as 2 . Then, a model was selected using one of the model selection criteria, namely $R^{2}$, the Akaike information criterion (AIC), the Schwartz Bayesian Criterion (SBC) or the Hannan-Quinn Criterion (HQC). The most appropriate ARDL $(2,1,1,0)$ model for Equation 7 was estimated according to the SBC. The long and short-term estimation results of the ARDL $(2,1,1,0)$ model in the case of FUR's being the dependent variable are given in Table 5 .

Considering the long-term estimation results in Table 5, one can see that the variables PPI and Real_HDI are statistically significant at the level of 5\%. In the long term, the independent variables PPI and Real_HDI had negative signs and produced a negative effect on the dependent variable FUR. There is no significant relation between ICT and female unemployment in the long run.

Real_HDI has a significant and negative effect on FUR. In other words, an increase in Real_HDI significantly reduces FUR. It can be said that this result 
Table 5

Short and long-term coefficients

\begin{tabular}{|c|c|c|c|}
\hline Independent Variables & \multicolumn{2}{|c|}{ Short-term coefficients } & Long-term coefficients \\
\hline $\operatorname{lnFUR}_{\mathrm{t}-1}$ & \multicolumn{2}{|c|}{$0.673(4.274)^{* * *}$} & \\
\hline $\operatorname{lnFUR}_{\mathrm{t}-2}$ & \multicolumn{2}{|c|}{$-0.559(-3.290)^{* * * *}$} & \\
\hline lnReal_HDI ${ }_{t}$ & \multicolumn{2}{|c|}{$-9.467(-3.509)^{* * * *}$} & $-3.675(-3.298)^{* * * *}$ \\
\hline lnReal_HDI ${ }_{t-1}$ & \multicolumn{2}{|c|}{$6.212(2.590)^{* *}$} & \\
\hline $\operatorname{lnICT}_{t}$ & \multicolumn{2}{|c|}{$-0.235(-2.181)^{* *}$} & $0.030(1.320)$ \\
\hline $\ln \mathrm{ICT}_{\mathrm{t}-1}$ & \multicolumn{2}{|c|}{$0.261(2.350)^{* *}$} & \\
\hline $\operatorname{lnPPI} I_{t}$ & \multicolumn{2}{|c|}{$-0.144(-1.831)^{*}$} & $-0.162(-2.420)^{* *}$ \\
\hline $\mathrm{C}$ & \multicolumn{2}{|c|}{$1.364(2.069)^{*}$} & \\
\hline \multirow[t]{2}{*}{$\mathrm{ECM}_{\mathrm{t}-1}$} & \multicolumn{2}{|c|}{$-0.886(-7.035)^{* * *}$} & \\
\hline & \multicolumn{2}{|c|}{ Diagnostic Tests } & \\
\hline $\mathrm{R}^{2}$ & 0.826 & $\chi_{B G}^{2}$ & $2.143[0.342]$ \\
\hline$\overline{\mathrm{R}}^{2}$ & 0.755 & $\chi_{\text {RAMSEY }}^{2}$ & $0.067[0.947]$ \\
\hline DW & 1.5915 & $\chi_{\text {NORM }}^{2}$ & $2.148[0.342]$ \\
\hline$F$ statistics & 11.554 & $\chi_{B P G}^{2}$ & $6.623[0.469]$ \\
\hline
\end{tabular}

Note: ${ }^{* * *} p<0.01,{ }^{* *} p<0.05,{ }^{*} p<0.10$. The values within brackets are $\mathrm{t}$ statistic values. $\chi_{B G}^{2}, \chi_{R A M S E Y}^{2}, \chi_{N O R M}^{2}$ and $\chi_{B P G}^{2}$ are tests used for respectively: Breusch-Godfrey serial dependence, Ramsey model establishment error in regression, Jarque-Bera normality and BreuschPegan-Godfrey heteroscedasticity testing. The values in square brackets represent p-probability values belonging to diagnostic tests. The error term (ECM) series was found to be stable at the level $(\mathrm{p}<0.01)$.

Source: compiled using e-View software.

was compatible with economic expectations. In the long term, a $1 \%$ increase in Real_HDI decreased FUR by $3.675 \%$, which is consistent with the literature. However, considering some earlier studies there is a significant and negative (Yıldırım and Karaman, 2003; Yuceol, 2006; OECD 2009) relation between the unemployment level and long-term economic growth (Aghion and Howith, 1994; Erikson, 1997; Braunninger and Pannenberg 2002). Some other studies suggest that growth does not reduce unemployment (Taymaz, 1999; Erlat, 2000; Dietzenbacher and Senesen, 2003; Tunali, 2004; Sayin, 
2012).Likewise, of other independent variables estimated, PPI was also found to have a significant and negative effect on FUR, and a $1 \%$ increase in PPI decreases FUR by $0.162 \%$. These results correspond to those of earlier studies emphasizing the relation between unemployment and inflation (Samuelson and Solow 1960; Berentsen et al. 2011).

An examination of the coefficients of the independent variables estimated in the long term, revealed that the human development index is the variable which had the biggest effect in terms of lowering female unemployment in the long run.

After the long-term relation was established, the error terms obtained and the difference values of the variables were used to estimate the short-term relation. The short-term results estimated are given in Table 5, and are similar to the long-run ones. The current periods value of Real_HDI showed an insignificant difference, but negatively affected FUR.

Similarly, a significant and negative relation was detected between ICT and female unemployment in the short term. This result shows that the use of ICT in the short term decreases female unemployment. It is possible to interpret this result as follows: innovations such as the smartphone and mobile Internet, facilitate access to information and increase knowledge, also for women. This situation helps women to show their abilities over time. Therefore, new jobs in the ICT area increase women's knowledge levels and their employment prospects. There is also a significant relationship between PPI and FUR in the short term. The coefficient for PPI is significant at the 10\% level in the short term. In other words, the value of PPI value had negative effects on female unemployment, and this effect was found to be significant.

On the other hand, as seen in Table 5, the fact that the $\mathrm{ECM}_{\mathrm{t}-1}$ error correction coefficient was negative and statistically significant confirms the long-term relation between female unemployment and Real_HDI, ICT and PPI. Thus, the lagged $\mathrm{ECM}_{\mathrm{t}-1}$ was correct in sign and very significant even at the $1 \%$ percent level. The error correction coefficient was estimated at -0.886 , and its sign is negative. Therefore, it can be said that any deviation in female unemployment in the short term may be corrected by $88.6 \%$ in the next period to attain the long-term balance. At the same time, this means that the model is significant and works.

Looking at the diagnostic test results of the $\operatorname{ARDL}(2,1,1,0)$ model in Table 5, one finds that the $\mathrm{p}$ (probability) values for the tests for serial correlation, heteroskedasticity, regression specification error and normality are greater than all $\alpha$ significance levels (1\%,5\% and 10\%). Hence it can be said that there was no diagnostic test problem established for the ARDL $(2,1$, $1,0)$ model. 


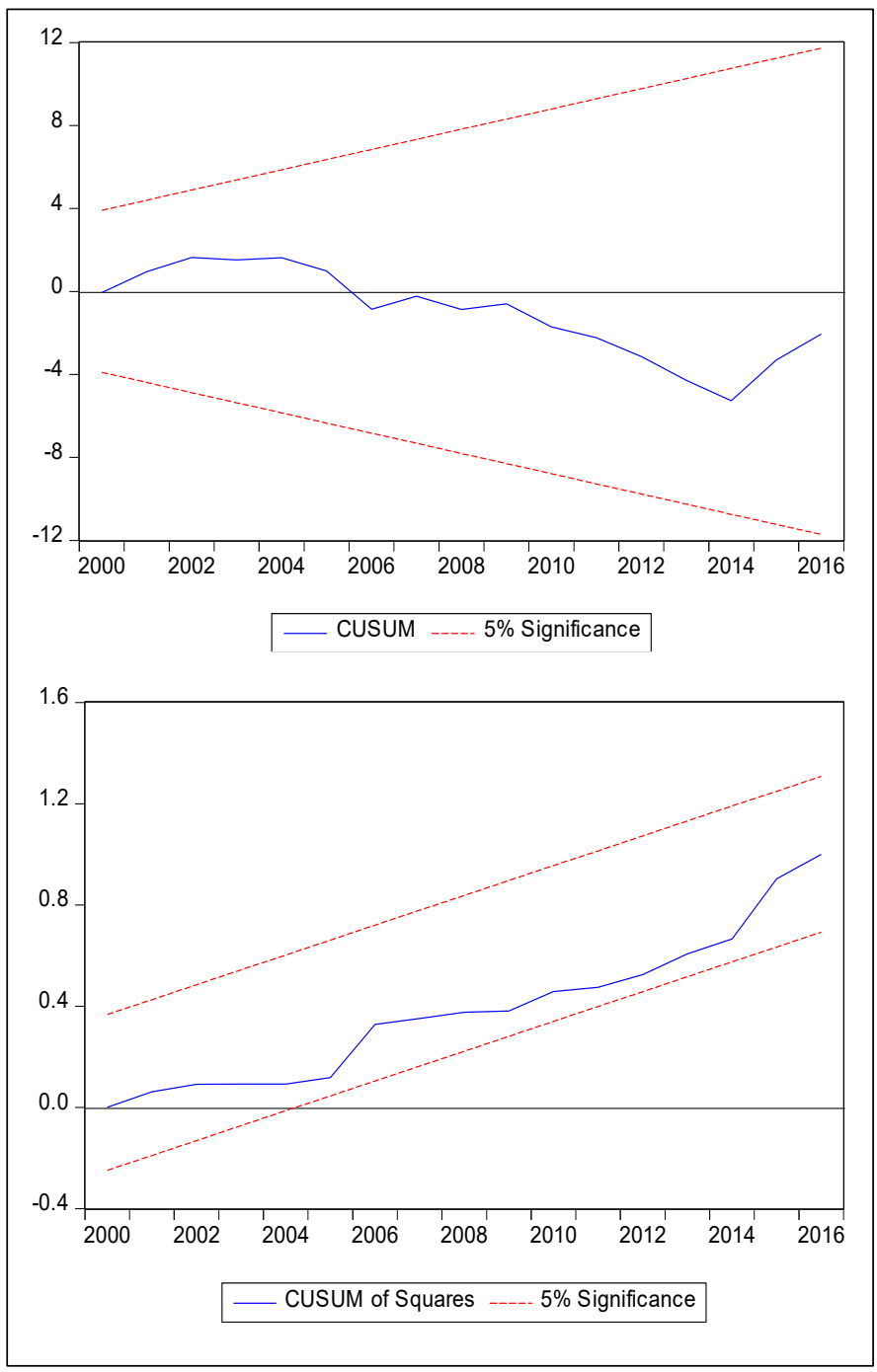

Fig. 3. CUSUM and CUSUMQ figures (1990-2016).

Source: compiled using e-View software.

Finally, to investigate the structural break concerning the variables, the CUSUM and CUSUM Q charts which used the squares of recurrent residuals to examine the structural break related to the variables, were employed. Figure 3 shows the CUSUM and CUSUM Q charts, respectively, where one can see both the CUSUM test and the CUSUMSQ test, which is more sensitive, and 
indicate that the model's residuals remain within the limits and the parameters are stable and there is no structural change in the model. Therefore, given the CUSUM and CUSUM Q charts in Figure 3, the long-term coefficients obtained through the estimation of the ARDL model were consistent.

\subsection{Granger causality test}

The cointegration analysis shows that there is a long-term relation between the variables, however it does not give any information about the direction of causality. According to Engle and Granger (1987), if there is a cointegration relationship between the variables, there is at least one unidirectional causality between the variables and this situation should be tested by the causality test based on the Vector Error Correction Model (VECM).In this context, the causality test results based on VECM are given in Table 6.

Table 6

The Causality Test Results

\begin{tabular}{|c|c|c|c|c|}
\hline Variables & $\operatorname{lnFUR}$ & $\operatorname{lnReal}{ }_{-} \mathrm{HDI}_{\mathrm{t}}$ & $\operatorname{lnICT}$ & $\ln \mathrm{PPI}$ \\
\hline & \multicolumn{4}{|c|}{$F$ statics ( $p$ value) } \\
\hline $\operatorname{lnFUR}$ & & $\begin{array}{c}0.209 \\
(0.889)\end{array}$ & $\begin{array}{c}1.541 \\
(0.9240)\end{array}$ & $\begin{array}{l}1.8572 \\
(0.233)\end{array}$ \\
\hline lnReal_HDI ${ }_{t}$ & $\begin{array}{l}3.203^{* *} \\
(0.049)\end{array}$ & & $\begin{array}{c}1.521 \\
(0.245)\end{array}$ & $\begin{array}{c}1.146 \\
(0.360) \\
\end{array}$ \\
\hline $\operatorname{lnICT}$ & $\begin{array}{l}5.316^{* * *} \\
(0.009)\end{array}$ & $\begin{array}{c}0.911 \\
(0.456)\end{array}$ & & $\begin{array}{c}0.729 \\
(0.549) \\
\end{array}$ \\
\hline $\ln P P I$ & $\begin{array}{c}1.467 \\
(0.480)\end{array}$ & $\begin{array}{c}1.311 \\
(0.519)\end{array}$ & $\begin{array}{c}0.002 \\
(0.998)\end{array}$ & \\
\hline
\end{tabular}

$H_{o}$ hypothesis "Granger has no causality relationship between variables". *** and ** respectively, with express significance on $1 \%$ and $5 \%$ significance levels.

Source: authors calculations in EViews.

The results of the causality test in Table 6 show that there is one-way causality between Real_HDI and FUR, InICT and FUR.In other words, it can be said that Real_HDI and InICT affected the FUR variable and were Granger cause. These results indicate that human development and ICT play an important role in female unemployment in Turkey. 


\section{CONCLUSION}

In this study the ARDL-bounds test method, developed by Pesaran et al. (2001), was employed to analyse the relation between female unemployment and human development and inflation using annual data. The stationarity of the series was tested using the ADF method and all the series belonging to the variables were found to be I(1). As a result of the cointegration analysis, a long-term relation was identified between human development, female unemployment and inflation for the period 1990-2016 in Turkey.

In the ARDL test, the coefficients related to the Real Human Development Index and inflation variables were as expected from an economic perspective and the human development index and inflation rate were found to have a fairly strong negative effect on female unemployment in a statistically significant manner for the period between 1990 and 2016 in Turkey. In the short term, the RHDI had a negative effect on female unemployment for the current period. The effect of the inflation rate on female unemployment was negative both in the short and long term, and the existence of an inverse relationship between inflation and unemployment was proven. These findings imply that the components of the RHDI are the main determinants of female unemployment in Turkey. Moreover, it was determined that ICT significantly and negatively impacted on female unemployment in the short term. These findings indicate that the use of ICT contributes to reducing female unemployment in Turkey.

Tansel (2002) also found positive labour force participation on growth rate in the gross provincial product per capita in Turkey. Some studies point to a significant and negative relation between the unemployment level and education (Green et al. 2000; Sayin, 2012). Similarly, in some studies it was found that education had a positive effect on the labour force participation rate (Mammen and Paxson, 2000; Tansel, 2002; Vlasblom and Schippers,2004; Dayioglu and Kirdar, 2010; Ercan et al. 2010). Others authors indicate that there is a significant and positive relation between the female labour force participation and health, a component of human development (Zhang et al.2009; Cai, 2010; Vecchio et al. 2014).

Accordingly, the government has a major role to play in reducing female unemployment. The government should increase public spending on educational services, health services and projects designed to increase income levels in order to lower female unemployment. In recent years in Turkey, the increase in compulsory education from eight to twelve years of age has also promoted an increase in female enrolment rates at all levels of schooling. Naturally, this does not mean that any increase in this public spending will 
always make a positive contribution to the efforts to minimize female unemployment. In this context, the government should adopt a fair and compensatory approach that would secure effective results in public services related to the components of development. In doing so, it should formulate developmental economic policies that would directly affect female unemployment free from inflationary pressures. In this context, comprehensive active employment policies for social and economic development should be developed, rather than passive employment policies, in order to decrease the rate of female unemployment. Women should be guided with career counselling in line with market demand, and additionally regional incentive systems should be used to encourage female entrepreneurship in areas where unemployment has become a major issue. Furthermore, the existing incentive policies should be expanded and implemented decisively.

\section{REFERENCES}

Aghion, P., Howith, P., Growth and unemployment, The Review of Economic Studies, 61(3), pp. 477-494, http://dx.doi.org/10.2307/2297900, 1994.

Alper, F. Ö., Bilgi ve iletişim teknolojilerinin ekonomik büyüme ve işsizlik üzerine etkisi: seçilmiş AB ülkeleri ve Türkiye örneği [The impact of information and communication technologies on economic growth and unemployment: The case of selected EU countries and Turkey], Yasama Dergisi, 36, pp. 45-65, 2017.

Artan, S., Hayaloğlu, P., Baltacı, N., Bilgi ve iletişim teknolojilerindeki gelişmelerin iktisadi büyüme üzerindeki etkisi: Geçiş ekonomileri örneği [The effects of information and communication technologies on economic growth: the case of transition economies], Atatürk Üniversitesi İktisadi ve İdari Bilimler Dergisi, 28(1), pp. 199-214, 2014.

Baslevent, C., Onaran, O., The effect of export-oriented growth on female labor market outcomes in Turkey, World Development, 32(8), pp. 1375-1393, https://doi.org/10.1016/j. worlddev.2004.02.008, 2004.

Berentsen, A., Menzio, G., Wright, R., Inflation and unemployment in the long run, American Economic Review, 101, pp. 371-398, 2011.

Berik, G., Yana van der Meulen, R., Stephanie, S., Feminist economics of inequality, development and growth, Journal of Feminist Economics, 15(3), pp. 1-33, https://doi.org/10.1080/ $13545700903093524,2009$.

Brauninger, M., Pannenberg, M., Unemployment and productivity growth, an empirical analysis within an augmented Solow model, Economic Modelling, 19(1), pp. 105-120, http://dx.doi. org/10.1016/S0264-9993(00)00065-1, 2002.

Briggs, A., The welfare state, a historical perspective, "Archives Europeennes de Sociologie", 2(2), pp. 221-258, 1999. http://dx.doi.org/10.1017/S0003975600000412

Cai, L., The relationship between health and labour force participation: Evidence from a panel data simultaneous equation model, Labour Economics, 17, pp. 77-09, http://dx.doi.org/ 10.1016/j.labeco.2009.04.001, 2010. 
Dayıglu, M., Kırdar, M., Türkiye'de Kadinlarin İşü̈cüne Katiliminda Belirleyici Etkenler ve Eğilimler [Determinants of and trends in labor force participation of women in Turkey], DPT ve Dünya Bankası, Refah ve Sosyal Politika Analitik Çalışma Programı, Çalışma Raporu Say1, 5, pp. 1-82, 2010.

Demir, S., Birleşmiş Milletler Kalkınma Programı Insani Gelişme Endeksive Türkiye Açısından Değerlendirme [United Nations Development Program Human Development Index and evaluation in terms of Turkey], Devlet Planlama Teşkilatı. Sosyal Sektörler ve Koordinasyon Genel Müdürlüğ̈̈, Ankara, 2006.

Dickey, D. A., Fuller W. A, Distribution of the estimators for autoregressive time series with a unit root, Journal of the American Statistical Society, 74(366), pp. 427-431, https://doi.or g/10.1080/01621459.1979.10482531, 1979.

Dickey, D. A., Fuller W. A., Likelihood ratio statistics for autoregressive time series with a unit root, Econometrica, 49(4), pp. 1057-1072, http://dx.doi.org/10.2307/1912517, 1981.

Dietzenbacher, E., Senesen, G. G., Demand-pull and cost-push effects on labor income in Turkey 1973-1990, Environment and Planning, 35(10), pp. 1785-1807, https://doi. org/10.1068/a35302, 2003.

Duflo, E., Women empowerment and economic development, Journal of Economic Literature, 50(4), pp, 1051-1079, http://dx.doi.org/10.1257/jel.50.4.1051, 2012.

Eggleston, K., Jensen, R., Zeckhauser, R., Information and Communication Technologies, Markets, and Economic Development a significant role for ICTs in the development process, [in:] Kirkman, G., Cornelius, P., Sachs, J., Schwab (eds.) The global information technology report 2001-2002: Readiness for the networked world. Oxford University Press Oxford, Chapter 7, pp. 62-74, August 3, 2020, https://cyber.harvard.edu/itg/libpubs/gitrr2002_ch07. pdf, 2002.

Elson, D., Gender equality and economic growth in the World Bank world development report 2006, Feminist Economics, 15(3), pp. 35-59, https://doi.org/10.1080/13545700902964303, 2012 .

Engle, R. F., Granger, C. W. J., Co-integration and error correction, representation, estimation and testing, Econometrica, 55(2), pp. 251-76,. http://dx.doi.org/10.2307/1913236, 1987.

Ercan, H., Hoşgör, A. G., Yılmaz, Ö., Factors that affect women's labour force participation and suggestions for provincial employment and vocational education boards: Ankara, Gaziantep and Konya, Ankara: ILO Office and the Turkish Employment Agency, https:// www.yumpu.com/en/document/read/10486621/factors-that-affect-womens-labour-forceparticipation-and-, 2010.

Erikson, C., Is there a trade-off between employment and growth?, Oxford Economic Papers New Series, 49(1), pp. 77-88, http://dx.doi.org/10.1093/oxfordjournals.oep.a028598, 1997.

Erlat, G., Measuring the impact of trade flows on employment in the Turkish manufacturing industry, Applied Economics, 32(9), pp. 1169-1180, http://dx.doi.org/10.1080/ $000368400404317,2000$.

Green, C., Loon, A., Mangan, J., Youth labor markets, education and employment destination, result from the Queensland Survey of Youth, Labor Market Research Unit Department and Training, 2000, Working Paper no. 1, retrieved March 13, 2017. https://www.researchgate. net/publication $/ 237376883$.

Hill, M. A., King, E., Women's education and economic well-being, Feminist Economics, 1(2), pp. 21-46, https://doi.org/10.1080/714042230, 1995. 
Jahan, S., Measuring human development: evolution of the human development index, Oxford Training Course, UNDP and QEH, 2002.

Johansen, S., Statistical analysis of cointegration vectors, Journal of Economic Dynamics and Control, 12(2-3), pp. 231-254, http://dx.doi.org/10.1016/0165-1889(88)90041-3, 1988.

Johansen, S., Juselius, K., Maximum likelihood estimation and inference on cointegration with applications to the demand for money, Oxford Bulletin of Economics and Statistics, 52(2), pp. 169-210, http://dx.doi.org/10.1111/j.1468-0084.1990.mp52002003.x, 1990.

Kasnakoglu, Z., Dayığlu, M., Measuring the value of home production in Turkey [in:] Bulutay, T. (ed.), The new developments in national accounts, pp. 73-97. DİE, Ankara 2002.

Kavak, Y., Eğitim, istihdam ve işsizlik ilişkileri [Education, employment and unemployment relations], Hacettepe Üniversitesi Eğitim Fakültesi Dergisi, 13, pp. 21-26, 1997.

Keskin, A., Ekonomik kalkınmada beşeri sermayenin rolü ve Türkiye [The role of human capital in economic development of Turkey], Atatürk Üniversitesi İktisadi ve İdari Bilimler Dergisi”, 25(3-4), pp. 125-153, 2011.

Klasen, S., Does gender inequality reduce growth and development? Evidence from cross country regressions, Policy Research Report on Gender and Development, 1999, WP no. 7. http://siteresources.worldbank.org/INTGENDER/Resources/wp7.pdf. Accessed March 13, 2017.

Klasen, S., Lamanna, F., The impact of gender inequality in education and employment on economic growth, new evidence for a panel of countries, Journal of Feminist Economics, 15(3), pp. 91-132, https://doi.org/10.1080/13545700902893106, 2009.

Lahoti, R., Swaminathan, H., Economic development and women's labor force participation in India, Journal of Feminist Economics, 22(2), pp. 1-28, https://doi.org/10.1080/13545701.2 015.1066022, 2016.

Mammen, K., Paxson, C., Women's work and economic development, The Journal of Economic Perspectives, 14(4), pp. 141-164, http://dx.doi.org/10.1257/jep.14.4.141, 2000.

Ministry of Labor and Social Security, Ulusal istihdam stratejisi 2014 [National employment strategy 2014], Ankara 2014.

Mitra, A., Bang, J. T., Biswas, A., Gender equality and economic growth, is it equality of opportunity or equality of outcomes?, Journal of Feminist Economics, 21(1), pp. 110-135, https://doi.org/10.1080/13545701.2014.930163, 2015.

Narayan, P., Narayan, S., Estimating income and price elasticities of imports for Fiji in a cointegration framework, Economic Modelling, 22(3), pp. 423-438, http://dx.doi. org/10.1016/j.econmod.2004.06.004, 2004.

Narayan, P. K., The saving and investment nexus for China: Evidence for cointegration tests, AppliedEconomics, 37(17),pp. 1979-1990, http://dx.doi.org/10.1080/00036840500278103, 2005.

Navarro, J. L., Ruiz, V. R. L., Peña, D. N., Economic growth and intangible capitals: Europe versus Asia, Panoeconomicus, 3, pp. 261-274, http://dx.doi.org/10.2298/PAN1403261N, 2014.

Nussbaum, M. C., Women and human development: The capabilities approach. Cambridge University Press, Cambridge, https://doi.org/10.1017/CBO9780511841286, 2000.

OECD, Jobs for youth (des emplois pour les jeunes) Australia, 2009. htpp://www.iadb.org./ intal/intalcdi/PE/2009/03432.pdf. Accessed January 11, 2016. 
OECD Data, Employment, Unemployment. https//data.oecd.org/ Accessed June 09, 2016

OECD Stat, Labour force statistics by sex and age, http//stats.oecd.org/viewhtml. aspx?datasetcode=LFS_SEXAGE_I_R\&lang=en Accessed January 11, 2016.

Palaz, S., Toplumsal cinsiyet ve kalkinma: kalkinmada kadinin yeri [Gender and development: women's place in development], [in:] Kar, M., Taban, S. (eds.), Iktisadi Kalkınmada Sosyal, Kültürel ve Siyasal Faktörlerin Rolü [The Role of Social, Cultural and Political Factors in Economic Development]. Ekin Kitabevi, Bursa 2005.

Perron, P., The great crash, the oil price shock, and the unit root hypothesis, Econometrica, 57, pp. 1361-1401, http://dx.doi.org/10.2307/1913712, 1989.

Pesaran, H., Shin, Y., Smith, R. J., Bounds testing approaches to the analysis of level relationships, Journal of Applied Econometrics, 16(3), pp. 289-326, http://dx.doi.org/10.1002/ jae.616, 2001.

Pradhan, R. P., Girijasankar, M., Bagchi, T. P., Information communication technology (ICT) infrastructure and economic growth: A causality evidenced by cross-country panel data, IIMB Management Review, 30(1), pp. 91-103, https://doi.org/10.1016/j.iimb.2018. 01.001, 2018.

Samuelson, P. A., Solow, R. M., Problem of achieving and maintaining a stable price level, analytical aspects of anti-inflation policy, American Economic Review, 50(2), pp. 177-194, 1960.

Sayın, F., Analysis of the impact of the education and growth in Turkey from 1988 to 2010 on youth employment, Dokuz Eylül University The Journal of Graduate School of Social Sciences, 13(4), pp. 33-53, 2012.

Seguino, S., Gender inequality and economic growth, a cross-country analysis, World Development, 28(7), pp. 1211-1230, http://dx.doi.org/10.1016/S0305-750X(00)00018-8, 2000.

Sen, A., Editorial, human capital and human capability, World Development, 25(12), pp. 1959-1961, http://dx.doi.org/10.1016/S0305-750X(97)10014-6, 1997.

Sen, A., Development as Freedom. Oxford University Press, New York 1999.

Taban, S. and Kar, M., Human capital and economic growth, causality analysis, 1969-2001, “Anadolu University Journal of Social Sciences”, 6(1), pp. 159-181, 2006.

Taban, S., Kar, M., Kalkınma ekonomisi [Development Economics], Ekin BasımYayım Dağıtım, Bursa 2014.

Tansel, A., İktisadi kalkinma ve kadinlarin işgücüne katilimi: Türkiye'den zaman-serisi kanitlari ve illere gore yatay kesit kestirimleri, [Economic development and women's labour participation: time-series evidence from Turkey and by provinces horizontal sections], Economic Research Center Middle East Technical University, ERC Working Papers in Economics 01/05T, http://www.erc.metu.edu.tr/menu/series01/0105T.pdf, Ankara 2002.

Tatli, H., Kadınların işgücüne katılımının belirleyicileri: Bir mikro uygulama [Determinants of women's labor force participation: A micro application], "Is, Guc" The Journal of Industrial Relations and Human Resources, 17(4), pp. 215-238, 2015.

Taymaz, E., Trade liberalization and employment generation, the experience of Turkey in the 1980s, Middle East Technical University Economic Research Center, Working Paper No: 99-11, Ankara, 1999.http://www.inovasyon.org/pdf/et.mm.emp.pdf

TUIK (Turkish Statistical Institute) Data, Gross enrolment ratio in tertiary education by sex, 2007-2018, August 10,2020, http://www.tuik.gov.tr/PreTablo.do?alt_id=1018 
TUIK (Turkish Statistical Institute) Data, Female labor force participation rate, August 10, 2020, https://biruni.tuik.gov.tr/medas/?locale=tr

Tunali, I., Labor market and employment researches in Turkey, Employment Report of the Turkish Labor Agency, Ankara University Publications, Ankara, 2004.

Turedi, S., Bilgi ve iletişim teknolojilerinin ekonomik büyümeye etkisi: Gelişmiş ve gelişmekte olan ülkeler için panel veri analizi [The impact of information and communication technologies on economic growth: Panel data analysis for developed and developing countries], Gümüşhane Üniversitesi Sosyal Bilimler Elektronik Dergisi, 7, pp. 298-322, 2013.

Ugur, N. G., Turan, A.H., Bilgi ve iletişim teknolojilerinin istihdama etkisi: G-20 ülkeleri üzerine ampirik bir çalışma [The effect of information and communication technologies on employment: An empirical study of G-20 countries], Finans Politik \& Ekonomik Yorumlar, 53(615), pp. 77-87, 2016.

UNDP, Human Development Report 2010, UNDP, New York 2011.

Uraz, A., Aran, M., Hüsamoğlu, M. Sanalmış, D.O. and Çapar, S., Recent trends in female labor force participation in Turkey, State Planning Organization of the Republic of Turkey and World Bank welfare and social policy analytical work program, Working Paper No. 2. http://dx.doi.org/10.1596/27838, Ankara, 2010.

Vecchio, N., Mihala, G. Sheridan, J., Hilton, M. F., Whiteford, H., Scuffham, P. A., A link between labor participation, mental health and class of medication for mental well-being, Economic Analysis and Policy, 44(4), pp. 376-385, http://dx.doi.org/10.1016/j.eap.2014.11.006, 2014.

Vlasblom, J. D., Schippers, J. J., Increases in female labour force participation in Europe: similarities and differences, European Journal of Population, 20(4), pp. 375-392, http:// dx.doi.org/10.1007/s10680-004-5302-0, 2004.

Wagman, B., Nancy, F., Household services and economic growth in the United States, 1870 1930, Journal of Feminist Economics, 2(1), pp. 43-66, https://doi.org/10.1080/738552685, 1996.

Wanjala, B. M., Maureen, W., Gender disparities and economic growth in Kenya, a social accounting matrix approach, Journal of Feminist Economics, 15(3), pp. 227-251, https:// doi.org/10.1080/13545700902893114, 2009.

Yüceol, H. M., Dynamics of economic growth and unemployment relations in Turkey, Economics, Business and Finance, 21(243), pp. 81-95, 2006.

Yıldırım, K., Karaman, D., Makro Ekonomi [Macroeconomics], Education, Health and Scientific Research Studies Foundation, 145, Eskişehir, 2003.

Zhang, X., Zhao, X., Harris, A., Chronic diseases and labour force participation in Australia, Journal of Health Economics, 28(1), pp. 91-108, http://dx.doi.org/10.1016/j.jhealeco. 2008.08.001, 2009.

Zivot, E., Andrews, D. W. K., Further evidence on the great crash, the oil-price shock, and the Unit Root Hypothesis, Journal of Business \& Economic Statistics, 10(3), pp. 251-270, http://dx.doi.org/10.2307/1391541, 1992.

Received: August 2020, revised: May 2021 